\title{
癌性胸膜炎に対する治療成績および 抗癌剤の胸膜透過性
}

\author{
Treatment of Carcinomatous Pleurisy and Pleural Permeability \\ of Anticancer Agents
}

カレッドレシャード・北野司久・藤尾彰・池修

竹内吉喜 · 望月吉郎 ${ }^{*} \cdot$ 綱谷良一 ${ }^{*} \cdot$ 種田和清 ${ }^{*}$

岩田猛邦 ${ }^{*} \cdot$ 人見滋樹 ${ }^{* *} \cdot$ 前里和夫 ${ }^{* *} \cdot$ 高橋憲太郎 ${ }^{* *}$

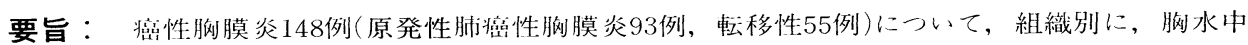

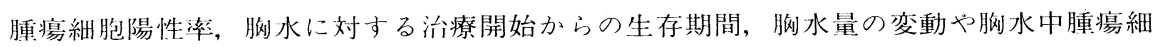
胞の消失および抗癌剤に対する刻膜透過性を解析検討した。胸水中腫瘍細胞陽性率73\% で，治療により原発性の脑膜炎の $64.7 \%$ ，また転移性の $80 \%$ に朐水中腫瘍細胞が消失し た。治療開始からの平圴生存期間は原発性癌性脸膜炎では 6 ヶ月，転移性のものでは 9.9 ヶ月であった。局所療法としてはMMC, MMC+OK432, CQ+5FUの胸腔内投与や胸腔 ドレナージおよびタルク注入法が有効であった。抗嵒剂(MMC, ADM, CPM, FT)に対 する胵膜透過性を42例に検討したところ, 蜰膜肥厚例で, 胸膜透過性は胸膜の肥厚度に 逆相関した。

\section{はじめに}

各種悪性腫瘍の胸膜播種，または胸膜の血流 やリンパ流の循環不全により併発する癌性胸膜 炎はTNM分類ではT 3 ，病期III に分類され，末期 癌として対症療法の適応疾患とみなされる場合 が多い。しかし，患者にとっては高度の呼吸困 難などの臨床症状を来たし，早期に処置を必要 とする場合も少なくない。さらに多量の蛋白を 含む胸水の頻回穿刺排液のため血清蛋白の減少 による体力の消耗を来たすため, 早期に胸水の 再貯留を防ぎ呼吸機能の改善を目的とした治療

天理よろづ相談所病院胸部外科

$$
\text { 同呼吸器内科 }
$$

** 関西電力病院呼吸器科
法が必要である。

癌性胸膜炎の治療としては抗癌剂の全身投与, 病側胸壁に対する放射線治療, そしてそれら治 療法とともに胸腔穿刺や胸腔ドレナージによる 排液後に, 抗癌剂, 免疫賦活剂, タルクやラジ オアイソトープなどの胸腔内投与による胸膜癒 着術などがある。抗癌剤の単独全身療法よりも， 全身療法と同時に, 胸膜刺激作用や值接癌細胞 に接触する抗癌剂の局所投与法の方が癌性胸膜 に対してより効果的と予想される.

著者らは過去10年間に148例の癌性胸膜炎症例 を経験し，胸腔穿刺や胸腔ドレナージと同時に 胸腔内に各種の抗癌剂, OK432やタルク等を注 入した症例の治療成績を検討したので報告する。 
一方，これら薬剤の胸膜を介しての移行につ いても検討したので合わせて報告する。

\section{対象および方法}

昭和 55 年 12 月までの約 10 年間に入院中胸水の 細胞診で異型細胞を認め, 癌性胸膜炎と診断さ れた148例を対象症例とした。胸水貯留の有無は 胸部レ線, 胸部CTにて判定し, 組織型は胸水の 細胞診, 胸膜生検などによって決定した。

148例中原発性肺癌症例は93例で, 年令は32 81 才平均68.1才)で，男性58例に対し女性は35 例であった。一方病側としては, 右側胸水貯留 例は46例で, 左側 40 例, そして両側性のものは 7 例であった。

癌性胸膜炎に対する治療は，胸腔穿刺にて胸 水を完全に排出した症例は35例で，1 例につき 平均3.8回の胸腔穿刺を行った。また胸腔穿刺に て排液後抗癌剂やOK432を胸腔内に注入した症 例は28例であった。一方，胸腔ドレナージおよ び低圧持続吸引を52例に54回施行した。胸腔ド レナージのみおよび全身療法を19例に行ったの で，これらの症例を治療成績上胸腔内薬剤投与 例と比較検討した。なお，平均ドレナージ日数 は16.75日であった。

胸腔内に注入した薬剤としては Mitomycin C (以下MMC), Adriamycin(以下ADM), 5FU, Esquinon(以下CQ), OK432を単独または混合で 生食 $20 \mathrm{ml}$ に溶解して使用した。胸腔内ドレナー ジ例ではタルク $2 \sim 6$ gr 5 例の胸腔内に注入 した,タルク注入後に胸膜より激痛が生じたら すぐに1000～3000mlの生食で洗條を行った。

他臓器原発による続発生癌性胸膜炎は55例で, うち乳癌21例, 消化器系の悪性腫瘍による症例 は13例, 女性性器癌 6 例, 悪性胸腺腫 4 例, 悪 性リンパ腫 3 例, 甲状腺癌 2 例, 腎癌 2 例, 悪 性中皮腫 2 例, そして肉腫系腫瘍による胸膜炎 は 2 例であった。

これらの症例は右側22例, 左側21例, そして 両側は12例であった。なお，乳癌症例が多いた めか原発性肺癌症例と対照的に女性が37例と多 かった。続発性癌性胸膜炎症例の年令は $13 \sim 80$ 才(平均52.6才)で, 原発性肺癌症例上り若年者
に多かった。

続発性癌性胸膜炎に対する治療は, 胸腔穿刺 を18例に行い，1症例に平均 4 回施行した。ま た30例に胸腔ドレナージおよび低圧持続吸引を 平均13.5日間行った。なお，7例に対し全身状 態不良のため積極的な治療を行わなかった。

これら症例の胸腔内に注入した薬戍は原発性 肺癌に上る癌性胸膜炎の治療中に使用した薬剤 と同じである。

癌性胸膜炎の治療後の効果判定は日本肺癌学 会, 化学療法効果判定基準に従った。

なお，癌性胸膜炎に対する胸膜癒着術の効果 判定には胸腔造影法を応用した。

抗癌剂に対する胸膜透過性を検討するため癌 性胸膜炎14例の胸腔内にMMC10mgおよびADM $20 \mathrm{mg}$ を注入し, その末梢血中の薬剤濃度を検討 した。

薬剂の胸膜透過性は, 肺の虚脱度, 胸水量, 胸郭の運動や胸膜の肥厚度などに左右される。 そこで, 著者らは胸膜の肥厚を有する癌性胸膜 炎症例と容易に比較できるょうに，原発性肺癌 13例の手術時の閉胸直前に同薬剂を胸腔内に投 与した後, 経時的にその血中濃度を測定し, 比 較検討した。また，全身投与が主である masked compounds $の$ Cyclophosphamide (以下CPA), Futraful(以下FT), ADMやMMCを全身投与し た後, 経時的にその胸水中濃度を胸水貯留早期 例 (即ち胸膜肥厚の少ない例)や頻回胸水貯留例 (即ち胸膜肥厚例)に測定検討した。

薬剮の血中おょび胸水中濃度はMMCはE.Coli を使用したbioassay法, ADMは螢光法, CPA は Friedman法そそしてFTはTraycer法で測定した。 なお, 胸水貯留例では胸水糖値と血糖値を測定 比較し, 胸膜胼胝の有無および組織所見との関 連性を検討した。

\section{成 績}

\section{(1) 原発性肺癌による癌性胸膜炎に対する治療} 成績

原発性肺癌による癌性胸膜炎はTable1のよj に93例で，その病理組織学的な分布は，腺癌54 例 $(58 \%)$, 扁平上皮癌 21 例 (23\%), 大細胞癌 5 


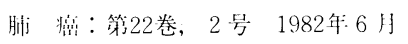

Table 1. Histological distribution, treatment effectiveness and survival time of carcinomatous pleuritis patients due to primary lung cancer.

\begin{tabular}{|c|c|c|c|c|c|c|c|}
\hline Histological type & $\begin{array}{l}\text { Adeno. } \\
\text { carcinomas }\end{array}$ & $\begin{array}{l}\text { Squamous cell } \\
\text { carcinomas }\end{array}$ & $\begin{array}{l}\text { Large cell } \\
\text { carcinomas }\end{array}$ & $\begin{array}{r}\text { Small cell } \\
\text { carcinomas }\end{array}$ & $\begin{array}{l}\text { Alveolar cell } \\
\text { carcinomas }\end{array}$ & Others & Total \\
\hline No. of cases & $\begin{array}{c}54 \\
(58 \%)\end{array}$ & $\begin{array}{c}21 \\
(23 \%)\end{array}$ & $\begin{array}{c}5 \\
(5.4 \%)\end{array}$ & $\begin{array}{c}3 \\
(3.2 \%)\end{array}$ & $\begin{array}{c}1 \\
(1.02 \%)\end{array}$ & $\begin{array}{c}9 \\
(9.7 \%)\end{array}$ & 93 \\
\hline $\begin{array}{l}\text { Positive cases of tumor cells } \\
\text { in pleural effusion }\end{array}$ & 48 & 8 & 3 & 3 & 1 & 5 & $\begin{array}{c}68 \\
(73.1 \%)\end{array}$ \\
\hline $\begin{array}{l}\text { Negativity of tumor cells in } \\
\text { pleural effusion after freatment }\end{array}$ & 32 & 5 & 2 & 2 & 1 & 2 & $\begin{array}{c}44 \\
(64.7 \%)\end{array}$ \\
\hline $\begin{array}{l}\text { Decreased pleural } \\
\text { effusion cases }\end{array}$ & 34 & 15 & 2 & 3 & 1 & 3 & $\begin{array}{c}58 \\
(62.4 \%)\end{array}$ \\
\hline $\begin{array}{l}\text { Survival times } \\
\text { (in months) }\end{array}$ & 6.9 & 3.7 & 3.2 & 22.4 & 2.0 & 2.9 & 6 \\
\hline
\end{tabular}

例 (5.4\%), 小細胞浯 3 例 (3.2\%), 肺胞上皮性 腺癌 1 例 $(1.02 \%)$ ，そして，その他の組織型を 有するものは 9 例 $(9.7 \%)$ であった。

上記の症例では左右差はなく，また両側胸水 貯留例は 7 例であった。

a) 腳水中腫瘍細胞の陽性率およびその治療によ る㓌性化

治療前に腳水中の腫瘍細胞の有無が検索され た84症例における胸水中腫瘍細胞の陽性率は73.1 \%(68例)であった。組織型別の比較では腺癌が $88.9 \%(48 / 54)$ と最毛高率で, 扁平上皮癌では $38.1 \%(8 / 21)$, 大細胞癌では60\%(3/5), 小細胞 癌および肺胞上皮性腺癌では各100\%(3/3, 1/1) であった。その他の組織型を呈した癌性朔膜炎 9 例のうち 5 例 $(55.6 \%)$ 胸水中に腫瘍細胞が 認められた。

治療前の胸水中の細胞診陽性症例68例に対し 加療したところ, 治療後は44例 $(64.7 \%)$ の刖水 中腫瘍細胞が陰性化した。各組織別に胸水中腫 瘍細胞の陰性化を比較してみると，他の組織刑! で示された症例の他，特別な差はなかった。

b) 治療による胸水量の減少率

胸水量の減少または 4 週間以上不変であった 症例は58例 $(62.36 \%)$ で, 組織型別のそれは腺癌 $34 / 54(63 \%)$, 聏平上皮癌 $15 / 21(71.4 \%)$, 大細 胞癌 $2 / 5(40 \%)$, 小細胞癌 $3 / 3(100 \%)$, 肺胞上皮
性腺癌1/1(100\%), その他群3/9(33.3\%)であっ た。小細胞癌や肺胞上皮性腺猿性脸膜炎に対市 る治療効果は最毛高かった。

C) 原発性肺癌に上る癌性刖膜炎の治療後の生存 期間

癌性胸膜炎に対する治療開始からの平均生存 期間は6 6 月で, 組織型別では次の通りである. 腺癌 6.9 个月で13/54 $(24.0 \%)$ が生存中で,これ ら 13 例の平圴生存期間は 14.6 个 月である。扁平 上皮癌は平坋3 3.5 个月で, 2 例が 8.5 个月後の現

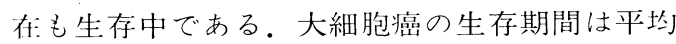
3.2 ヶ 月で, 小細胞癌のそれは 22.4 ヶ 月で, その うち肺結核および子宮頸部癌を合併した 1 例は 治療開始52 ケ月後の現存: 毛生存中である。肺胞 上皮性腺癌例や他組織群症例の平均生存期間は 約 2 ケ月であった。

d) 原発性肺癌による癌性胸膜炎に対する治療内 容およびその効果 (Table2)

癌性別膜炎に対する治療成績を肺癌学会化学 療法効果判定基準によって評価した。胸水およ び腫瘍細胞がともに消失し，4週間以上再発を 認めないもの (著効) と胸水減少, 腫瘍細胞が消 失し， 4 週間以上胸水の増加を認めないもの(有 効)をTable2のごとく effectiveとし, 各化学療法 別に判定した。

原発性肺癌による胸膜炎の治療として35例 
Table 2. The effectiveness of treatment against carcinomatous pleuritis in primary lung cancer patients

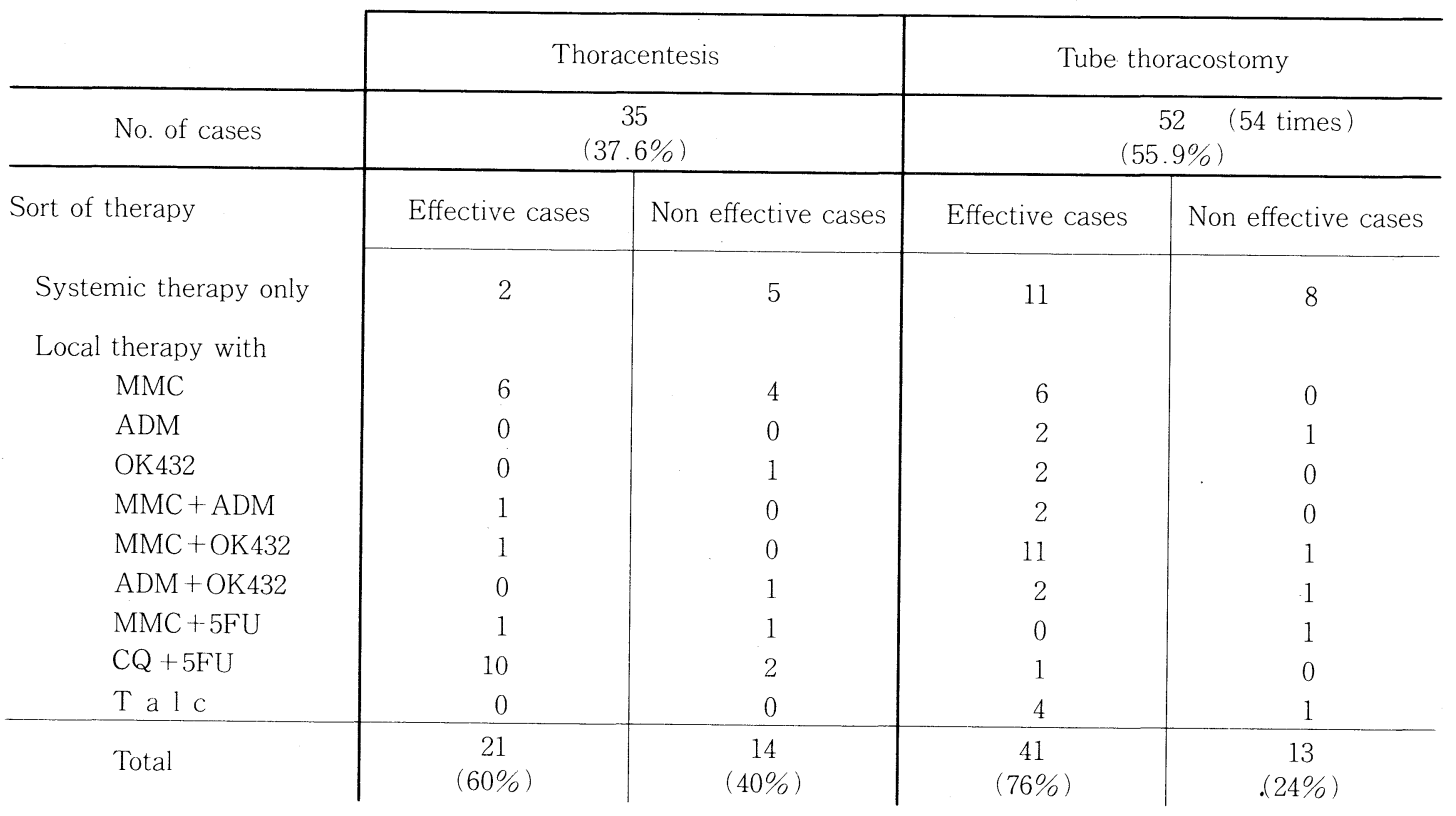

$(37.6 \%)$ に対し胸腔穿刺および52例 $(55.9 \%)$ に 対し胸腔ドレナージを行なった。残り6例は全 身状態不良, または患者の治療拒否のため無治 療に終った。

Table2のごとく, 全身化学療法のみを行った 症例では, 胸腔穿刺例には無効例が 7 例中 5 例 と多く, 胸腔ドレナージを行った症例では, ド レナージのみでも腳膜癒着が得られるためか有 効な症例は19例中11例と多かった。

胸腔穿刺や胸腔ドレナージ中に行った局所療 法としてMMC, MMC+OK432, CQ+5FU, およ びドレナージ例ではタルク注入例には有効率が 高かった。上記の治療成績として, 胸腔穿刺例 （局所療法を伴なわない症例を含む）では有効率 は60\%(21/35)に対して,胸腔ドレナー-ジ例のそ れは76\%(41/52) とより高い成績を得な。なお， 積極的な治療を行之なかった 6 例中， 5 例の生 存期は平均28日であるのに対し，肺結核およで 帯状疮疹を合併した 1 例は 12 ヶ月の現在も生存 中である。これはhostの細胞性免疫が関与して 子後をよくしたと思われる興味深い症例である。

(2)転移性腫瘍による続発性癌性胸膜炎に対す る治療成績(Table3)
著者らが経験した転移性腫瘍による癌性胸膜 炎は55例で, その内訳は, 乳癌からの転移は21 例, 消化器系腫瘍より転移をしたものは13例, 女性性器腫瘍 6 例, 悪性胸腺腫 4 例, 悪性リン 八腫 3 例, 甲状腺腫瘍, 腎癌, 悪性中皮腫, 肉 腫系腫瘍各 2 例であった。

罹患側としては右22例, 左21例, 両側12例で あった。

a) 続発性癌性胸膜炎の胸水中腫瘍細胞の陽性率 および治療によるその㓌性化

治療前の胸水中腫瘍細胞の陽性率は乳癌症例 では76\%(16/21), 消化器系腫瘍 $61 \%(8 / 13)$, 女 性々器腫瘍 $67 \%(2 / 3)$ で, 甲状腺腫瘍, 腎癌, 悪 性中皮腫および肉腫系腫瘍は各100\%(2/2)であ った。続発性癌性胸膜炎全例では72.7\%(40/55) の胸水中に腫湯細胞が認められた。

上記の症例に対し治療を行った後に胸水中の 腫瘍細胞の院性化を検索して見ると，乳癌症例 では13/16(80.6\%), 消化器系腫瘍6/8(75\%), 女性々器腫瘍では4/4 (100\%), 覀性胸腺腫, 悪 性リンパ腫, 甲状腺腫瘍や悪性中皮腫は各 $2 / 2$ $(100 \%)$, 肉腫系では $1 / 2(50 \%)$ に胸水中の腫瘍 細胞が院性化した。䐌癌の 2 例は治療に反応せ 
Table 3. Histological distribution, treatment effectiveness and survival time of carcinomatous pleuritis due to metastatic lung tumors

\begin{tabular}{|c|c|c|c|c|c|c|c|c|c|c|}
\hline $\begin{array}{r}\text { Primary sources of } \\
\text { the tumors }\end{array}$ & $\begin{array}{c}\text { Mammary } \\
\text { cancer }\end{array}$ & $\begin{array}{l}\text { Gastrointe- } \\
\text { stinal } \\
\text { cancer }\end{array}$ & $\begin{array}{l}\text { Utero- } \\
\text { ovarian } \\
\text { tumors }\end{array}$ & $\begin{array}{l}\text { Malignant } \\
\text { thymomas }\end{array}$ & $\begin{array}{c}\text { Malignant } \\
\text { lymphomas }\end{array}$ & $\begin{array}{l}\text { Thyroid } \\
\text { tumors }\end{array}$ & $\begin{array}{l}\text { Kidney } \\
\text { tumors }\end{array}$ & $\begin{array}{l}\text { Mesothe- } \\
\text { liomas }\end{array}$ & Sarcomas & Total \\
\hline No. of cases & 21 & 13 & 6 & 4 & 3 & 2 & 2 & 2 & 55 & \\
\hline $\begin{array}{l}\text { Positive cases of } \\
\text { tumor cells in } \\
\text { pleural effusions }\end{array}$ & 16 & 8 & 4 & 2 & 2 & 2 & 2 & 2 & 2 & $\begin{array}{c}40 \\
(72.7 \%)\end{array}$ \\
\hline $\begin{array}{l}\text { Negativity of tumor cells } \\
\text { in pleural effusion } \\
\text { after treatment }\end{array}$ & 13 & 6 & 4 & 2 & 2 & 2 & 0 & 2 & 1 & $\begin{array}{c}32 \\
(80 \%)\end{array}$ \\
\hline $\begin{array}{l}\text { Decreased pleural } \\
\text { effusion cases }\end{array}$ & 15 & 4 & 5 & 2 & 2 & 2 & 0 & 2 & 1 & $(60 \%)$ \\
\hline $\begin{array}{l}\text { Survival time } \\
\text { (in months) }\end{array}$ & 14 & 4 & 6.6 & 12 & 6 & 13 & 1 & 14.5 & 8 & 9.9 \\
\hline
\end{tabular}

Table 4. The effectiveness of treatment against carcinomatous pleuritis in metastatic lung cancer patients

\begin{tabular}{|c|c|c|c|c|}
\hline \multirow{3}{*}{$\frac{\text { No. of cases }}{\text { Sort of therapy }}$} & \multicolumn{2}{|c|}{ Thoracentesis } & \multicolumn{2}{|c|}{ Tube thoracostomy } \\
\hline & \multicolumn{2}{|c|}{$\begin{array}{c}18 \\
(32.7 \%) \\
\end{array}$} & \multicolumn{2}{|c|}{$\begin{array}{c}30 \\
(54.5 \%) \\
\end{array}$} \\
\hline & Effective cases & Non effective cases & Effective cases & Non effective cases \\
\hline Systemic therapy only & 3 & 4 & 4 & 3 \\
\hline Local therapy with & & & & \\
\hline MMC & 4 & 1 & 4 & 0 \\
\hline $\mathrm{ADM}$ & 0 & 0 & 3 & 1 \\
\hline OK432 & 1 & 0 & 1 & 1 \\
\hline $\mathrm{MMC}+\mathrm{ADM}$ & 1 & 0 & 1 & 2 \\
\hline $\mathrm{MMC}+\mathrm{OK} 432$ & 2 & 0 & 3 & 1 \\
\hline $\mathrm{MMC}+5 \mathrm{FU}$ & 1 & 0 & 0 & 0 \\
\hline $\mathrm{CQ}+5 \mathrm{FU}$ & 1 & 0 & 1 & 0 \\
\hline $\mathrm{T}$ a $1 \mathrm{c}$ & 0 & 0 & 4 & 1 \\
\hline Total & $\begin{array}{c}13 \\
(72.2 \%)\end{array}$ & $\begin{array}{c}5 \\
(27.8 \%)\end{array}$ & $\begin{array}{c}21 \\
(70 \%)\end{array}$ & $\begin{array}{c}9 \\
(30 \%)\end{array}$ \\
\hline
\end{tabular}

ず，また胸水量の減少も認められなかった。以 上を総合すると 40 例中 32 例 $(80 \%)$ の)続発性胸水 中の腫瘍細胞が治療によって陰性化した。

b) 治療に上る続発性癌性胸膜炎の胸水量の減少 率

続発性癌性胸膜炎症例では, 胸水貯留の減少 が33/55(60\%)に認められ，原発性肺癌による胸
膜炎の治療成績と余り差はなかった。胸水量の 減少率は消化器系腫瘍は $30.76 \%(4 / 13)$ および腎 癌0/2 と低值を示した他は乳癌例 $71.4 \%(15 / 21)$, 女性々器腫瘍 $83.3 \%(5 / 6)$, 悪性胸腺腫と肉腫系 腫瘍は50\%(2/4,1/2), 悪性リンパ腫67\%(2/3), 甲状腺腫瘍と悪性中皮腫は各100\%(2/2)であっ た。 
Fig. 1. Pleural effusion is seen on chest X-ray in a carcinomatous pleuritic case (right lateral decubitus position).

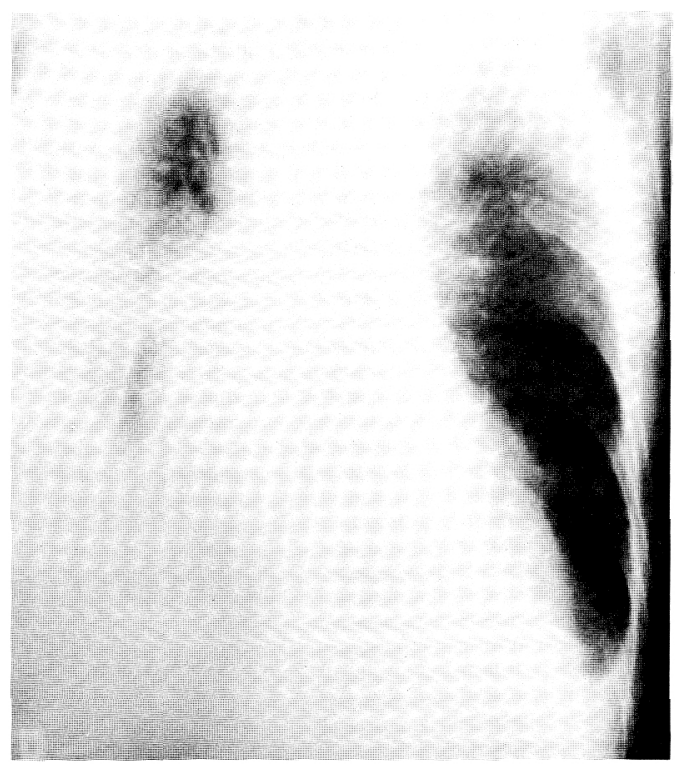

c) 続発性覀性胸膜炎に対方る活療後の生存期間 続発性癌性胸膜炎の治療開始後の平均生存期 間は9.9 个月間で, 原発性肺活性刖膜炎の平均生 存期間の 6 ケ月よりも3.9个月延言している。中

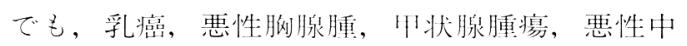

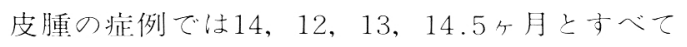
の平圴が12ヶ月以上となっている。これら55例

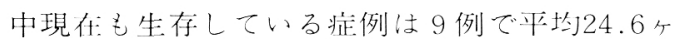
月間の生存期間維持している。特に乳癌性胸 膜炎 4 例は平均36.5 月月の長期間生存している. d) 続発性澺性啲膜炎に対古る治䝤内容およびそ の効果 (Table4)

続発性癌性䏫膜炎の18例 (32.7\%) に対し 1 例 平均 4 回の胸腟穿刺を行ないまた30例（54.5 \%)に対して胸腔ドレナージを施行した。なお， 苅腔ドレーンの平垖㨂入期間は13.5日間であっ た。

局所療法 (胸腔内薬剂注入) 例では有效率は91 $\%(10 / 11)$ 上高值を示し, また全身療法や䏫腔穿 刺のみを行なった症例を加えても72.2\%(13/18) の有効率であった。胸腔ドレナージ施行例では 有效率は70\%(21/30)で, 局所療法を行った症例 のみは74\%(17/23)であった。
Fig. 2. Thoracography after pleuredesis shows complete pleural adhesion.

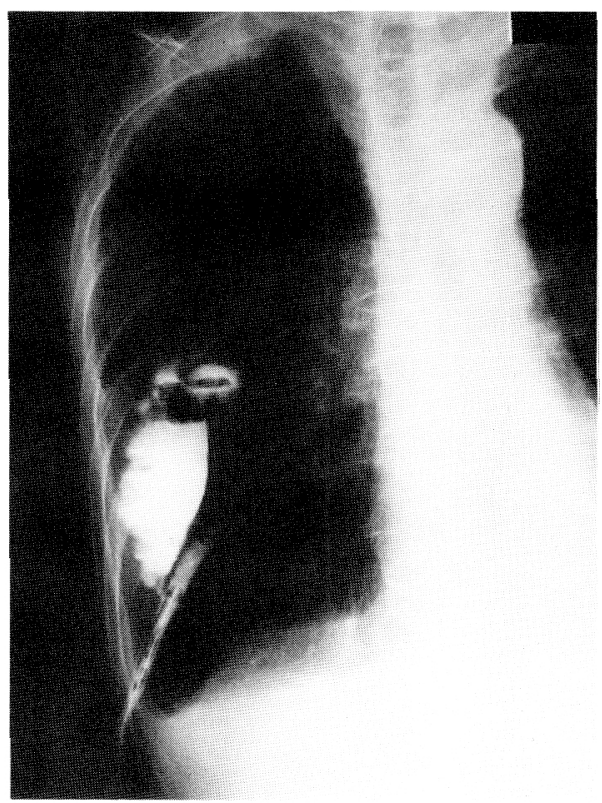

局所療法の種類としては原発性肺犃による癌 性冽膜炎症例々同様にMMC，MMC+OK432ゃ タルクの注入法が最も有効であった。胸腔穿刺 や胸腔ドレナージ等の穔敬的な汸療が出来なか つた 7 症例では全例が 1 ケ月以内に死亡してい る。この事実は積杫的な治療の必要性老示唆す るものである。

(3)癌性胸膜炎に対する胸膜癔着術の効果判定 癌性版膜炎の汸潦後仁成立子る胸膜癒着の成 否の判定やその癒着の範囲の確認はX線写具や 排液のみでは不可能な症例も少なくない。著者 らは咳性䐳膜炎に対しドレナージ法を行ったと ころドレーンより200－400mlの排液があるため ドレーンを30日以上も抜去しなかったところ死 後の剖検では刚膜は肥厚し，ほぼ全面癒着が見 られ，挿入ドレーンの周囲にわずか手拳大の限 局性の死腔のみが認めら扎た1症例老経験した。 このような炡例に刘して刚腔造影法を応用すれ ば，長期にドレナージを行う必要がないことが 判明交る。

Fig.1は両側癌性脑膜炎の 1 例の右側卧位胸部 レ線で出側に胸水貯留が認められる。右胸腔に 対して胸腔ドレナージを施行し，抗癌剂の䏫腔 
Fig. 3. Sequential changes of concentration of MMC in serum, on $10 \mathrm{mg}$ MMC intrapleural instillation, during thoracotomy.

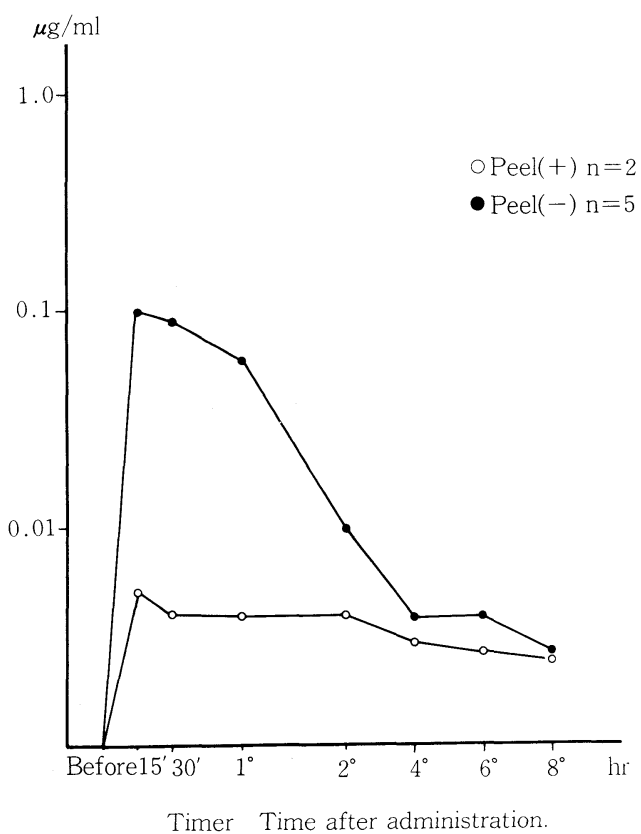

内投与を行っても，ドレーンよりの排液が減少 せぬため，胸膜癒着の範囲を知る目的で胸腔造 影を施行した。Fig.2のごとく，かなりの圧を加 えて造影剂を注入したが，これ以上広がらない ので，胸膜癒着必要にして充分に完成したと判 断し扳管した。

このように胸腔ドレーンからの胸腔造影法 ${ }^{2)}$ は，胸膜癒着の範囲を確実に知ることができる ので，扳管の時期の判定や予後の判定にもきわ めて有用である?

\section{(4)抗癌剤に対する胸膜の透過性}

薬剂に対する胸膜の透過性は胸水量, 肺の虚 脱の程度, 胸部の運動や胸膜肥厚度により変動 するので, 著者らは肺の虚脱度や胸水量が一定 である症例（胸部レ線や胸部CTにて判定を行っ た）を胸膜肥厚の有る群および無い群に分けて 比較検討した。

図では全て縦軸は薬剂の血中および胸水中濃 度を $\mu \mathrm{g} / \mathrm{ml}$ 単位で，横軸は時間を示し，黒丸は 胸膜肥厚のない症例の薬剤濃度を示している。 なお, $\mathrm{CPM}$ 静注後の胸水中濃度を示したグラフ
Fig. 4. Sequential changes of concentration of MMC in serum, and pleural fluid, on $10 \mathrm{mg}$ MMC intrapleural instillation, during thoracic intubation.

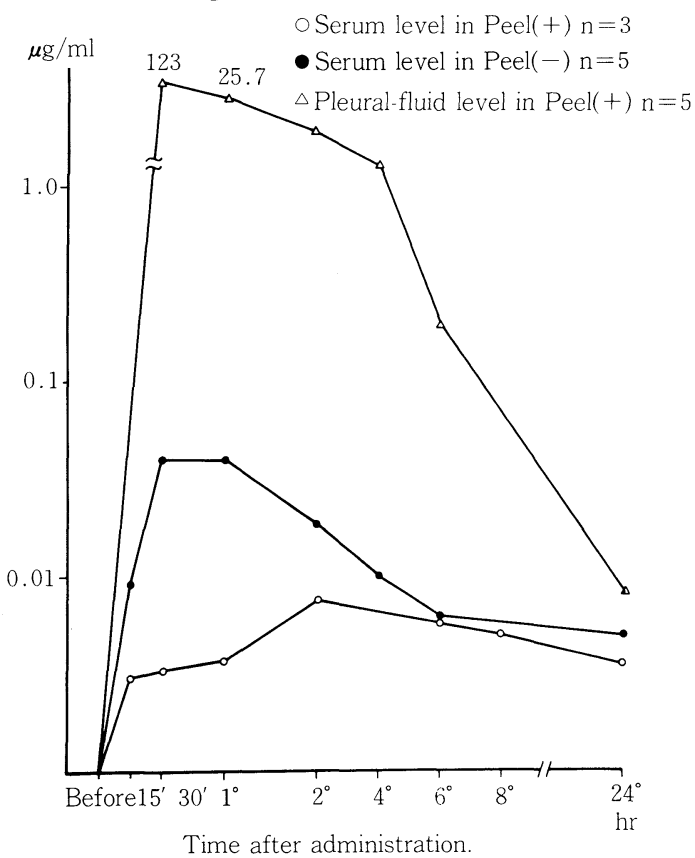

以外は片対数グラフを使用している。

a)胸腔内投与群の成績

i) $\mathrm{MMC}$ 胸腔内投与群

Fig.3はMMC10mgを手術例でその閉胸直前に， 胸腔内に投与した後，経時的に测定した血中濃 度を示す。白丸で示された 2 例のうち 1 例は癌 性胸膜炎による胸膜肥厚を有し，もう1例は広 範囲に術前照射を受けたため，胸膜の循環不全 を起こしたと思われる症例である。これら 2 例 ともにMMCは最高で0.007 $\mu \mathrm{g} / \mathrm{ml}$ の低血中濃度 を示している。それに対して胸膜肥厚のない 5 例では投与後測定した15分後に0.1 $\mu \mathrm{g} / \mathrm{ml}$ の最高 血中濃度が得られ，これは静注の場合とほとん ど同じ減少傾向を示している。

Fig.4は癌性胸膜炎の8例に対し胸腔ドレナー ジ中胸腔内にMMC10mgを注入した後，その血 中および胸水中濃度を示す。困 3 と同様白丸で 示す胸膜肥厚の完成された長期胸水貯留例では, 血中に移行した MMCの量は微量で, その最高 濃度は平均 $0.008 \mu \mathrm{g} / \mathrm{ml}$ で投与後 2 時間目に得 られている。そして，その減少傾向もゆるやか 
Fig. 5. Sequential changes of concentration of ADM in serum, after $20 \mathrm{mg}$ ADM intrapleural instillation during thoracotomy.

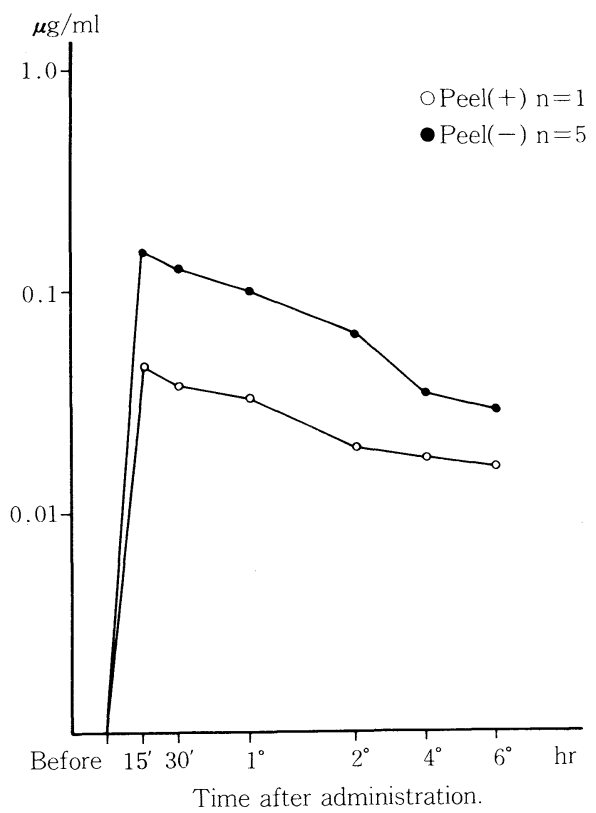

で投与24時間後まで有効な濃度として测定され る。それに対して黒丸で示された胸水貯留早期 例ではMMCの最高血中濃度は0.078 $\boldsymbol{\mu g} / \mathrm{ml}$ で投 与後30分に得られた。Fig.3で示された正常胸膜 例の最高血中濃度よりやや低值を呈しまたそ の時間も15分から30分遅延している. その減少 傾向はややゆるやかで，投与 24 時間までに測定 しえる值である。困中 $\triangle$ は胸膜肥厚例でMMCの 胸水中濃度を表わしたもので, 最高胸水中濃度 は $123 \mu \mathrm{g} / \mathrm{ml}$ で投与後 24 時間まで血中より高い有 効な濃度が得られた。これはMMCに対する胸膜 の透過性がその肥厚度に比例して低下しているこ とを意味する。

ii) ADM胸腔内投与群

手術例で閉胸直前に，ADM20mgを胸腔内に 投与した後測定した血中濃度をFig.5で示してい る。白丸で示された癌性胸膜炎の 1 症で最高血 中濃度は $0.07 \mu \mathrm{g} / \mathrm{ml}$ で，黒丸で示された正常胸 膜を呈する 5 例の最高血中濃度は $0.18 \mu \mathrm{g} / \mathrm{ml}$ と 比較し低值を示す。またその減少傾向にもはっき りした差が現われている。Fig.6は癌性胸膜炎の 6 例に対して胸腔ドレナージ中, 胸腔内にADM $20 \mathrm{mg}$ を注入した後，その血中濃度を示す。全例
Fig. 6. Sequential changes of concentration of ADM in serum, after $20 \mathrm{mg}$ ADM intrapleural instillation, during thoracic intubation, in thicken pleural cases.

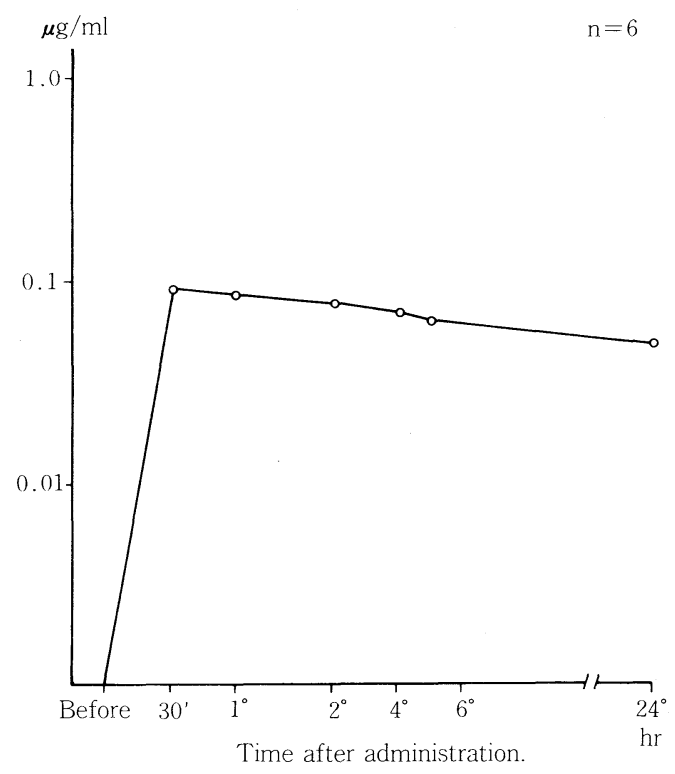

に胸膜肥厚が強度のため, ADMの最高血中濃度 は0.08 $\boldsymbol{\mu g} / \mathrm{ml}$ で，先述した正常胸膜例の最高血 中濃度の $50 \%$ 以下の值となっている。またその 減少傾向导ゆるやかで，投与 24 時間後まで有効 な濃度として测定される。

b) 静脈内投与群の成積

i) $\mathrm{MMC}$ 静脈内投与群

MMC10mg静脈内投与後の胸水中濃度はFig.7 のごとくである。強度の胸膜肥厚を有する 2 例 では, 白丸で示されるように, 最高胸水中濃度 は $0.01 \mu \mathrm{g} / \mathrm{ml}$ で，投与 4 時間後に得られ，その 後も胸水中に貯留し, 投与 24 時間後までに测定 されうる. 胸水貯留初回例では, 胸水中のMMC 濃度は, 胸腔内投与時の血中濃度と大差はなく, 投与後30分にピークが得られ，また胸膜からの 再吸収も迅速である。

ii) ADM静脈内投与群

Fig.8はADM20mgを静脈内投与した後に測定 した胸水中のADM濃度を示す。癌性胸膜炎のド レナージ中, ADM 20mg を胸膜肥厚を有する 2 症例と胸水貯留早期の 2 例に静注した。胸膜肥 厭を有する(白丸で示す)例で, 最高胸水中濃度 は0.085 $\mu \mathrm{g} / \mathrm{ml}$ で, その後も減少せず, 投与 24 時 
Fig. 7. Sequential changes of concentration of MMC in pleural fluid after intravenous injection of $10 \mathrm{mg} \mathrm{MMC}$.

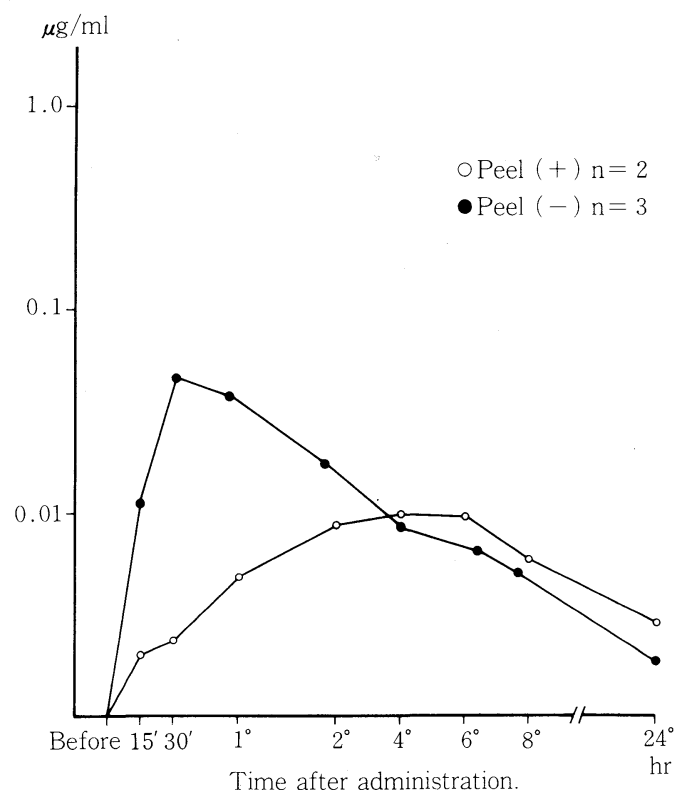

間後まで, $0.068 \mu \mathrm{g} / \mathrm{ml}$ の值を維持している。 そ れに対し, 胸水貯留早期例 (病理組織上胸膜の変 化の微少なもの) の最高胸水中濃度は胸膜正常 例のそれと等しい。そして, その減少傾向も早 く, 胸膜肥厚例とは対照的である.

iii) CPA 静脈内投与群

CPA やFTなどの masked compoundsは肝臓 において活性化されて局所へ移行する薬剤であ るため, 全身投与のみが有効である.Fig. 9 は胸 膜肥厚を有する 3 例にCPA1gを静注した後, そ の胸水中の濃度をn-mole $\mathrm{Eq} / \mathrm{ml}$ で表している。 胸膜肥厚度により胸水中のCPM 濃度が決定され, 肥厚の少ない 2 例では最高血中濃度は 1 時間後 に得られ43n-mole $\mathrm{Ea} / \mathrm{ml}$ の值を示すのに対し， 白丸で示される胸膜肥厚の強度な症例では, 最 高の胸水中濃度は遅れて 8 時間目に35n-mole $\mathrm{Eq} / \mathrm{ml}$ 值として現われている。いずれの症例で も投与 24 時間後まで有効な濃度として測定される。 iv) FT 750mg (坐薬) 投与後の胸水中濃度

Futraful 坐薬 $(750 \mathrm{mg})$ を肛門内に挿入し，こ の薬剤の胸水中への移行を調べた。成積は Fig. 10の通りで, FT 750mg 投与後のFT-207として の胸水中濃度を胸膜肥厚強度例は $\triangle て ゙$, 胸膜肥
Fig. 8. Sequential changes of concentration of ADM in pleural fluid after intravenous injection of $20 \mathrm{mg}$ ADM.

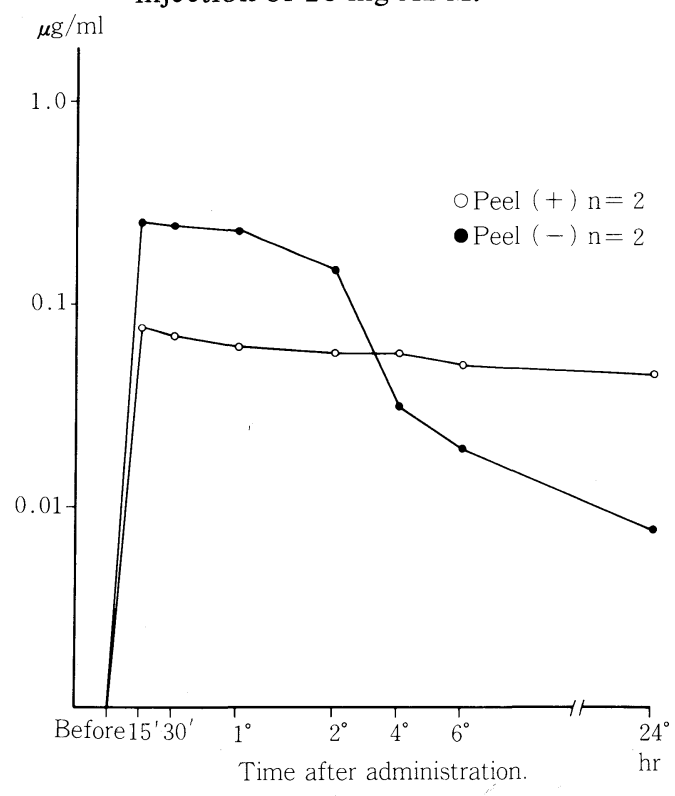

Fig. 9. Sequential changes of Concentration of CPA in pleural effusion after intravenous instillation of $1 \mathrm{~g} \mathrm{CPA}$.

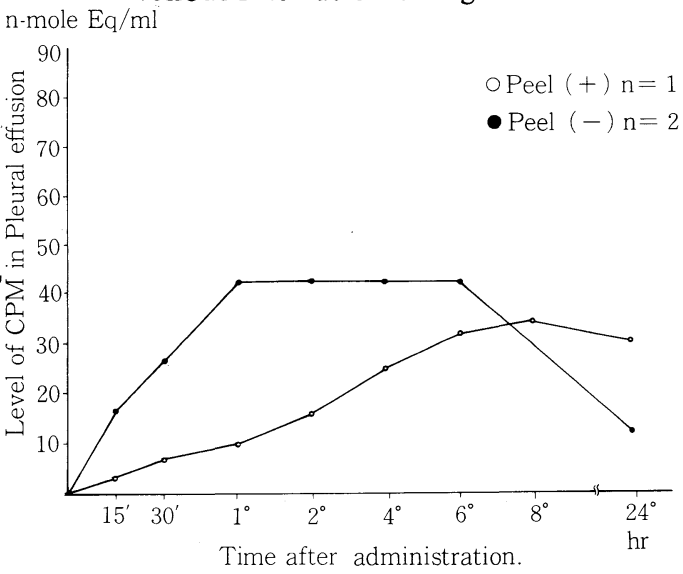

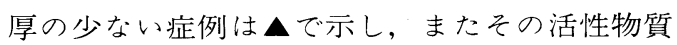
である5FUとしての胸水中濃度を胸膜肥厚強度 例は○で, 胸膜肥厚の少ない症例は・で示して いる。両方の胸膜肥厚度の少ない 2 例ともに他 の薬剤と同じパターンを示した。

(5)胸水貯留例における胸水糖値と血糖値の相 関

著者の 1 人，人見 ${ }^{4), 5)}$ および玉田 ${ }^{6)}$ は胸水糖值 と胸膜肥厚の関係を検索し胸膜肥厚例では胸水 
Fig. 10. Sequential changes of concentration of FT-207 and 5FU in pleural effusion after $750 \mathrm{mg}$ FT suppository instillation.

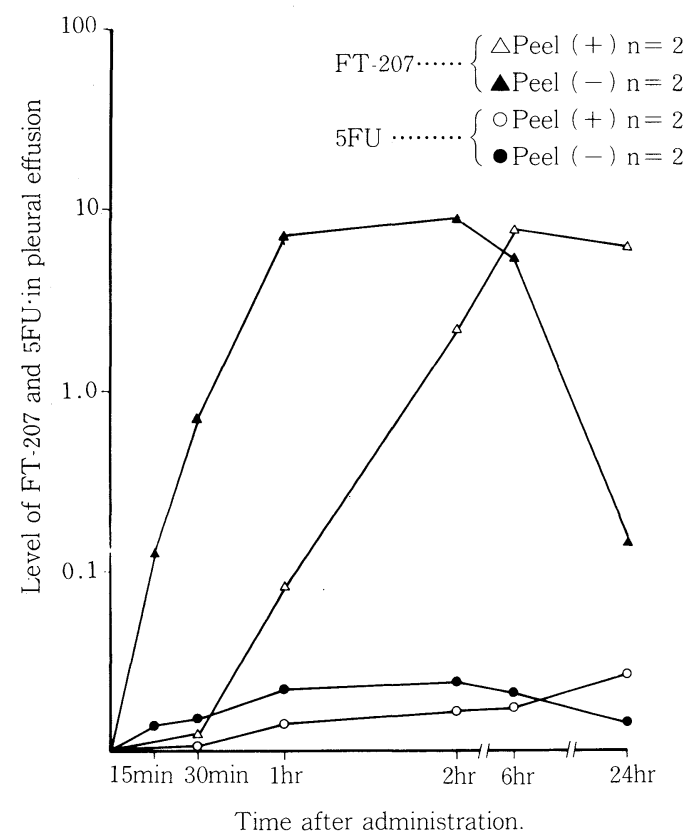

糖值が低下し，嫌気性解糖のため胸水中の乳酸 值が高值となることを報告している。

著者らはこの度さらに症例数を増やして，胸 水貯留例で, 腳水糖值と血糖值を比較検討し, 胸膜胼胝およびその組織所見との関連を検討し た。Fig. 11は60例で測定した胸水糖值(縦軸)お よび血糖值(横軸)を示している。○で示した胸 膜肥厚を有する24例で胸水糖值は血糖值に比較 して低值を示しまた胸膜肥厚のない（・で示 す）症例では胸水糖值は血糖値とほぼ同じ值を 示した。この結果として，胸水糖值を胸膜肥厚 の指標として使用できる。

\section{考案}

癌性胸膜炎例について胸水中腫瘍細胞の陽性 率および治療によるその㓌性化率, 胸水量の変 動や治療開始からの生存期間などを検討した。 さらに組織型別および原発等別にも検討した一 方，局所療法別の治療効果についても解析した。 胸水中の腫瘍細胞の出現率は, 原発性肺癌性 胸膜炎では73.1\%, 続発性癌性胸膜炎では72.2 \%といずれ毛高率を示した。A. O. Vladutiuら ${ }^{7}$
Fig. 11. Correlation of sugar level in serum and pleural effusion.

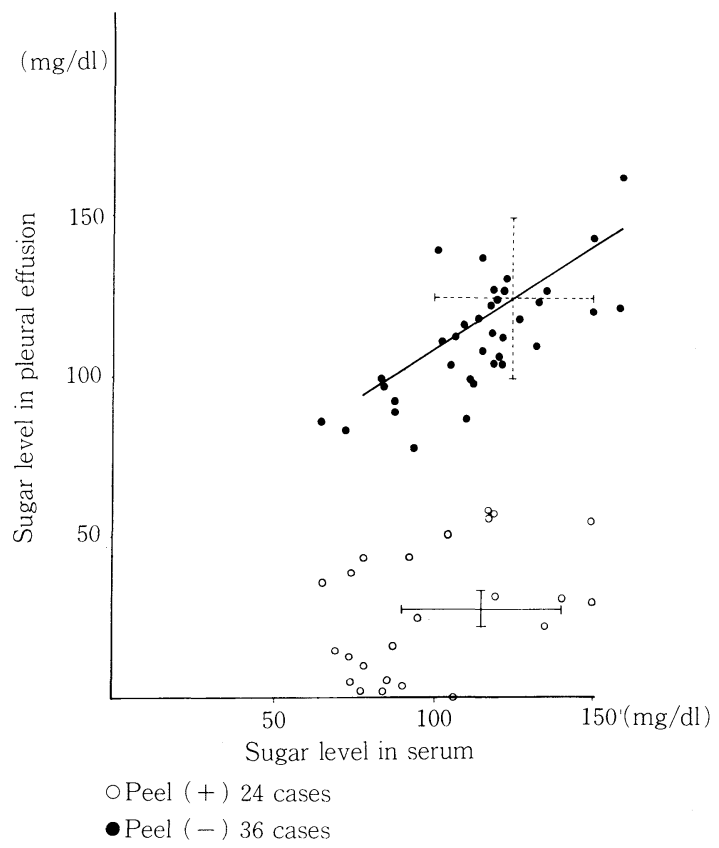

の報告による胸水中腫瘍細胞の陽性率50\%より も著者らはよい成績を得た。治療によってこれ ら胸水中腫瘍細胞の陰性化率は原発性肺癌では $64.7 \%$ ，続発性のものでは80\%であった。西條 $ら^{8)}$ は腺癌による胸膜炎の治療後, $41.9 \%$ に腫 瘍細胞の陰性化を認女，52.9\%に胸水減少を得 たと報告している。それに対し著者らは腺癌に よる胸膜炎の治療後に $67 \%$ の胸水中に腫瘍細胞 の陰性化を認め，また $70.8 \%$ に胸水減少を得た。 この值は他の組織型の治療成績と大差はなかった。 治療法別として, 胸腔穿刺十抗癌剂の局所療 法よりも胸腔ドレナージ十局所療法が効果的で あった。その理由としては胸腔ドレナージのみ でも十分な胸膜癒着が得られることが予想される。 癌性胸膜炎に対する治療開始からの生存期間 は原発性肺癌症例では平均 6 ケ月, 続発性のも のでは 9.9 ケ月で, 全例の平均生存期閒は 7.5 ヶ 月であった。この成績はMartini ら ${ }^{9)} の 6$ 月や Ariel ら ${ }^{10)}$ の 6.3 ヶ 月よりよい成績ではあるが, 西條ら ${ }^{8)}$ 0 8.0 个月よりはやや劣るものである。

癌性胸膜炎に対して胸膜癒着術を行った場合 にその成否と範囲の判定が重要である。臨床経 
験的に $1 \sim 2$ 週間の持続吸引で十分と判定した り，また排液の量の減少を指標としたりしてい る.しかし、これらはいずれも確実な方法とは 言えない，著者のいう胸腔造影法はドレーンよ り血管造影剤であるアンギオグラフィンを注入 することにより, 胸膜癒着の範囲を確実に知っ て抜管の時期や予後の判定に応用できる利点が ある。

癌性胸膜炎における胸水貯留は胸水の産生と 吸収のバランスがくずれることにより生じるも のである。このような胸膜からの吸収の著明な 減少は胸膜肥厚, 胸郭運動の減少や周囲の循環 不全などによって起こされる。

胸膜から薬剂の吸収は上述した因子の他に胸 水量, 薬剂の代謝および薬剂の分子量にて左右 される.11),12)

最近，抗癌剂に対する胸膜透過性についての 種々研究はなされている ${ }^{13) \sim 16)}$ が, 特に胸膜透過 性に及ぼす胸膜肥厚の影響は検討されていない。 勿論, 胸膜透過性と胸膜肥厚の相関々係は他の 因子を無視して考えることはできない。しかし， 胸壁の循環障害はなく, 肺の虚脱および胸水量 のほぼ一定な症例では, 胸膜透過性に影響を及 ぼす因子としては胸膜肥厚が最も重要である。

著者らは胸水量がほぼ同量と思われる14症例 の胸腔内にMMC, ADMを注入し, 胸膜肥厚の 有無を胸部CTおよび胸膜生検で検索した後, こ れら薬剤の血中への移行を胸膜肥厚度別に検討 した。一方, ADM, MMCの分子量間に大差は ないため, 分子量の差による胸膜透過性の変化 はないものと仮定できる。同様に胸水貯留のな い手術例にこれら薬剤を胸腔内の全面に散布す るように注入し，その血中への移行を検討した 結果, いずれの薬剤に対しても胸膜透過性は, 胸膜肥厚度に逆相関を示した。

逆に，血中に投与された薬剂の胸水中への移 行も同じようにその肥厚度により大きく変動した。

胸膜肥厚のある症例では胸腔内に投与した薬 剂は長時間胸腔内に貯留し, 投与 24 時間後毛有 効な濃度を維持している。一方，抗癌剂は多彩 な副作用を有するので，患者にとって，全身的 な副作用が少なく，局所に高濃度が得られる治
療法が望ましい，従って，胸膜肥厚例では，胸 腔内投与が全身的な副作用が少なくて安全かつ 有効な治療法である。このような胸膜肥厚によ る薬剂の胸膜透過性の変動や局所療法の有用性 はG.K. Thorsrud ら ${ }^{17)}$ の報告にも示唆されている。

著者らは60例の炎症性胸膜炎に対して, 抗生 剂を胸腔内おょび血中に投与し，その薬剤に対 する胸膜透過性を検討した。その結果は今回と 同様な成積を得た.

上記の検索の結果，胸膜肥厚例では安全に高 濃度の抗癌剂を局所に投与できることが判った。 また胸膜肥厚のない症例では抗癌剤の局所およ び全身の同時投与の場合は副作用の面から考慮 すべきである。

\section{結 語}

1. 肺原発性および続発性癌性胸膜炎 148 例に 対する治療内容および成績について検討した。

a）原発性肺癌性胸膜炎は93例で，その73.1 $\%$ 胸水中に腫瘍細胞が認められ，治療に てその $64.7 \% に$ 陰性化を認めた。また，こ れら症例の $62.4 \%$ に胸水量の減少を得, そ の治療開始からの平均生存期間は 6 ヶ月で あった。

b) 続発性癌性胸膜炎55例の胸水細胞診は72.7 \%に陽性で，治療によってその $80 \%$ に㓌性 化を認めた。胸水量減少は60\%に見られ， その平均生存期間は 9.9 ヶ 月であった。

c）癌性胸膜炎に対する治療内容としては, 胸腔内に $\mathrm{MMC}, \mathrm{MMC}+\mathrm{OK} 432, \mathrm{CQ}+5 \mathrm{FU}$ およびタルクの注入が最も効果的であった。

2 . 癌性胸膜炎に対する胸膜癒着術の効果判定 には胸腔造影法を応用した。

3 . 胸膜透過性を 42 例に検討し, 胸腔内にMMC, ADMを注入した後その血中濃度を，また同じ く MMC，ADM， CPA，FTを全身投与し， その胸水中濃度を測定, 比較検討した。

a) 胸膜肥厚例で，胸膜透過性は胸膜の肥厚 度に逆相関したため, 抗癌剂の胸腔内投与 は副作用が少なく，安全かつ有効であった。

b) 胸膜正常例では, 抗癌剂の胸腔内投与は, 副作用の面から全身投与と同様に考慮すべ 
きである。

4. 胸水糖值と血糖值を测定比較し, 胸膜胼胝 との関連を検討した。その結果，胸膜肥厚例 では胸水糖は低值を示すため, 胸膜肥厚度の
指標として使用できることが判った。

この論文の 1 部は第21回肺漓学会総会 $(1980.10$. 東京) および第21回日本脸部疾患学会総会 (1981。5.仙台) にて報告したものである。

\section{文 献}

1）化学療法放射線療法効果判定基準。肺癌, 20(4) : 441 446, 1980.

2）人見滋樹，池田貞雄，船津武志，他：胸腔造影 法の診断学的意義について。胸部外科, 24(10) : 706 713, 1971.

3) Reshad. K, 前田和夫, 人見滋樹: 自然気胸や胸 膜炎に対する胸膜痛着術の効果判定のための胸 腔造影法の意義. 胸部外科, 32(10)：760～764, 1974.

4）人見㵀樹，玉田二郎，前里和夫：胸水の鑑別. 肺之心，25(1)：65-73，1978.

5）人見滋樹, 玉田二郎, 前里和夫：癌性胸膜炎一 の対処一胸水の生化学的性状と胸膜癒着術を中 心に。肺癌, suppl. Sep. : 7, 1977.

6）王田二郎，前里和夫，人見滋樹：胸水糖低值症 例の検討。日胸疾会誌，16(2)：130，1978.

7) Vladutiu. A. O, Brason. F. W., Adler. R. H. : Differential diagnosis of pleural effusions. clinical usefullness of cell marker quantitation. Chest, 79(3): 297 301, 1981.

8）西条長宏, 西脇 裕, 川瀨一郎, 他：延命効果 からみた癌性䓡膜炎の治療成績。肺癌, 18(1)： 51 57, 1978

9) Martini. N, Bains. M. S., Beattie. E. J. : Indications for pleurectomy in malignant effusion. cancer, 35:734, 1975.

$10)$ Ariel. I. M., Oropeza. R., Pack. G. T. : Intracavitary administration of radioisotopes in the control of effusions due to cancer. cancer, 19: 1097, 1966.

11）佐川圭助：刖腔内投与制癌剂の脑水中および血 液中濃度の経時的推移。第 $\mathrm{I}$ 報：BLMについて の成績。肺将，15(1)：41～51，1975.

12）佐川圭助：胝腔内投与制嵒剂の胸水中および血 液中濃度の経時的推移。第 II 報：制癌剂MMC. 5ーFuおよび色素剂PSPについての成績。肺癌,
16(2): 141 151, 1976.

13）小室康男, 西島昭吾, 本間 威, 他: 癌性胸膜 炎に対する局所注入療法。肺癌, 20(1)：21～31, 1980.

14）中山修二：制癌剂を指票としてみた癌性胸膜腔 の透過性。肺癌, 18(2)：171 179, 1978.

15）本間 威, 小室康男, 西島昭吾, 他：抗癌剂胸 腔内投与時の生体内動態. I : Adriamycin の成 績。癌と化学療法, 7：(1)：67～72，1980.

16）本間 威, 米田修一, 小室康男, 他：抗癌剂胸 腔内投与時の生体内動態. II : Mitomycin-Cの 成績。癌と化学療法, 7(4)：700～706，1980.

17) Thorsrud. G. K. : Pleural reaction to irritants. Acta. Chir. Scand., 355, 1965.

18）K.レシャード, 池修, 北野司久：胸膜の抗 生剂の透過性. 最新医学, 12月号, 投稿中

19）前里和夫，K.レシャード，人見滋樹，他：胸膜 炎および膿胸の病態とその治療。外科治療，42 (6) : 697 706, 1980.

20) Wilson. J. L., Herrod. C. H., Searle. G. L., al. : The absorption of blood from the pleural space. Surg, 48(4): 766 774, 1960.

21) Courtice. F. C. and Simmonds. W. J. : Physiological significance of lymph drainage of the serous cavities and lungs. J. Physiol., 34(3): 419 448, 1954.

22）沢田勤也, 福間誠吾, 関 保雄, 他：癌性胸膜 炎に対する胸腔内持続吸引法を併用した制癌剂 投与に上る細胞学的研究. 日胸疾学誌, 18(6): 394 401, 1980.

23）高木啓吾 : 癌性胸膜炎の外科病理学的検討一全 胸膜肺切除例での検討。肺癌, 21(2)：161 175, 1981.

24) Starling. E. H., Tubby. A. H. : On absorption from and secretion into the serous cavities. J. Physiol., 16 : 140 155, 1894. 


\title{
Treatment of Carcinomatous Pleurisy and Pleural Permeability
}

\section{of Anticancer Agents}

\author{
Khaled Reshad, Morihisa Kitano, Akira Fujio, Osamu Ike, \\ Yoshiki Takeuchi, Yoshiro Mochizuki*, Ryoichi Amitani*, \\ Kazukiyo Oida*, Takekuni Iwata*, Kentaro Takahashi**, \\ Kazuo Maezato**, and Shigeki Hitomi**.
}

Tenri Yorozu Hospital Chest Surg. Dept.

* Tenri Yorozu Hospital Resp. Intern. Dept.

** Kansai Denryoku Hospital Chest Dept.

The incidence of tumor cells in pleural effusions, their disappearance after treatment and their relationship to survival time were studied in 148 cases (including 93 primary lung cancer and 55 metastatic pleurisy cases).

The positive rate of tumor cells in pleural effusion was $73 \%$, while the negative rate after treatment was $65 \%$ in primary pleurisies, and $80 \%$ in metastatic pleuritic cases. The effects of systemic chemotherapy and thoracocentesis or tube thoracostomy with local instillation of anti-cancer drugs were also evaluated. Tube thoracostomy and local instillation of anticancer agents and talc were more effective than thoracocentesis or systemic chemotherapy alone.

We have performed contrast thoracography after pleurodesis through the intrathoracic drain. The border of the adhesion was verified by change of position under fluoroscopy. It is thought to be the best method for confirming the extent of adhesion after pleurodesis and deciding the most suitable time for removing the intrathoracic drain.

Also in this study the permeability status of the pleural space was evaluated in 42 carcinomatous pleuritic cases. The sequential changes of concentrations of MMC and ADM in blood were measured following intrapleural instillation in 27 cases, and pleural fluid levels of MMC, ADM, CPA and FT were examined in 15 cases after systemic infusion. In patients without thickened pleuras, the permeability of the drugs was rapid, however in thickened pleural cases the permeability of the pleura was in inverse proportion to its thickness. Therefore in cases with thickened pleura the local instillation of the anticancer agents was more effective.

The level of glucose in pleural effusions of 60 cases was examined. It was quite low in cases of thickened pleura, however a high level of glucose as in serum was seen in normal cases. Therefore, the glucose level of the pleural fluid can be used as a marker of the pleural thickening. 